\title{
Molecular pathways in cancer-related inflammation
}

\author{
Annalisa Del Prete ${ }^{1,2 *}$, Paola Allavena ${ }^{1}$, Giuseppe Santoro ${ }^{3}$, Ruggiero Fumarulo ${ }^{3}$, Massimiliano M. Corsi ${ }^{4}$, Alberto Mantovani1 ${ }^{1,5}$ \\ ${ }^{1}$ Istituto Clinico Humanitas IRCCS, Via Manzoni 56, 20089 Rozzano, Milan, Italy \\ 2Department of Basic Medical Sciences, University of Bari, Bari, Italy \\ ${ }^{3}$ Department of Biomedical Sciences and Human Oncology, University of Bari, Bari, Italy \\ ${ }^{4}$ Department of Human Morphology and Biomedical Sciences "Città Studi", University of Milan, and Soc. Clinical Pathology and IRCCS \\ Policlinico San Donato, Milan, Italy \\ ${ }^{5}$ Department of Translational Medicine, University of Milan, Milan, Italy
}

*Corresponding author: annalisa.del_prete@humanitasresearch.it; delpreteanna@hotmail.com

\begin{abstract}
Accumulating evidence shows that chronic inflammation is associated to increased risk of cancer. An inflammatory component is present also in the microenvironment of tumours epidemiologically unrelated to inflammation. Extensive investigations over the past decade have uncovered many of the important mechanistic pathways underlying cancer-related inflammation. Pathways linking inflammation and cancer have been identified: an intrinsic one (driven by genetic events that cause neoplasia) and an extrinsic one (driven by inflammatory conditions which predispose to cancer). Smouldering inflammation is a component of the tumour microenvironment and is a recognized hallmark of cancer. Key orchestrators at the intersection of the intrinsic and extrinsic pathways include transcription factors (e.g. Nuclear Factor kappa-B, NFkB) that modulate the inflammatory response through soluble mediators (cytokines, chemokines) and cellular components (e.g. tumor-associated macrophages), promoting tumorigenesis. NFkB aids in the proliferation and survival of malignant cells, promotes angiogenesis and metastasis, subverts adaptive immunity, and alters responses to hormones and chemotherapeutic agents. Emerging evidence also suggests that persistent inflammation promotes genetic instability. Thus, cancer-related inflammation represents a target for innovative diagnostic and therapeutic strategies.
\end{abstract}

Key words: cancer-related inflammation; cytokines; chemokines; macrophages

\section{Introduction}

The German Pathologist Virchow is credited with suggesting the casual link between inflammation and cancer in the $19^{\text {th }}$ century (1). This conclusion was based on the observation that tumours often developed in the setting of chronic inflammation and that inflammatory cells were present in tumour biopsy specimens. Epidemiological studies have revealed that chronic inflammation predisposes to different types of cancer. It is estimated that underlying infections and inflammatory responses are linked to $15-20 \%$ of all death from cancer worIdwide $(2,3)$. The triggers of chronic inflammation which increase cancer risk include microbial infec- tions (e.g. Helicobacter pylori for gastric cancer and mucosal lymphoma), autoimmune diseases (e.g. inflammatory bowel disease for colon cancer), and cryptogenic inflammatory conditions of uncertain origin (e.g. prostatitis for prostate cancer). The strongest evidence in humans of the role of inflammation in cancer has been provided by studies showing that long-term therapy with anti-inflammatory drugs resulted in decreased numbers of relapses or fewer appearances of new tumours. Recently, Rothwell et al. (4) re-analyzed patient data from eight randomized trials of daily aspirin taken for prevention of cardiovascular disease. Aspi- 
rin users were found to have a significantly lower risk of death from cancer than those who didn't take the drug (4). Earlier studies reported that daily uses of aspirin and other non-steroidal anti-inflammatory drugs (NSAIDs) over extended periods reduced the risk of colorectal cancer or polyp recurrence, but little evidence was available that aspirin might also reduce risk of other cancers (5). In trials in which the patients took aspirin for at least 7.5 years, the 20-years risk of cancer death, starting from the time the trials began, was reduced by $60 \%$ for gastrointestinal cancer and by $30 \%$ on average for other solid cancers, such as oesophageal, pancreatic, stomach, lung, brain, and prostate cancers (4). These data indicate that anti-inflammatory drugs prevent both gastrointestinal and other solid-organ cancers, and suggest that an inflammatory component is present in the microenvironment of most neoplastic tissues, including those not etiologically related to an obvious inflammatory process.

Key features of cancer-related inflammation (CRI) include leukocyte infiltration, mostly tumour associated macrophages (TAM); the presence of cytokines such as TNF- $a$, IL-1, IL- 6 or chemokines such as CCL2 and CXCL8; and the occurrence of angiogenesis and tissue remodelling. Molecular and cellular pathways linking inflammation and cancer have been identified (2). Two general pathways can be schematically described. In the intrinsic pathway, genetic events (e.g. oncogenes, genetic aberrations) causing neoplastic transformation, initiate the expression of inflammation-related programmes which guide the construction of an inflammatory microenvironment. The extrinsic pathway is driven by inflammatory leukocytes and soluble mediators that establish inflammatory conditions that increase cancer risk. The chronic inflammation associated with the infections caused by most or all pathogens (e.g. Hepatitis B and $C$ viruses, and Helicobacter pylori) favours initiation and progression of tumours (6). In addition to infections, mechanical, radiation, and chemical insults may be responsible for induction of inflammation associated with human malignancy. Key orchestrators at the intersection of the intrinsic and extrinsic pathway include transcription factors [e.g. Nuclear Factor kappa-B (NFkB), Signal Transducers Activator of Transcription3 (STAT3)] $(7,8)$, cytokines (e.g. TNF), and chemokines (9). Thus, cancer-related inflammation is a key component of the tumour microenvironment and a recognized hallmark of cancer $(10,11)$. Here we will review both intrinsic and extrinsic pathways and their mutual connection and influence. Knowledge of these mechanisms may not only enhance our understanding of the process of carcinogenesis and of the multifaceted role played by inflammation, but could also help to identify new targets for therapeutic intervention.

\section{The intrinsic pathway links inflammation and oncogenes}

The presence of inflammatory components in tumours not epidemiologically related to inflammation raised the question of whether genetic events that cause neoplasia can be responsible for the generation of an inflammatory environment. This question has been addressed by using preclinical and clinical settings in which various oncogenetic mechanisms can be assessed. A useful clinical example of connection between oncogenes and inflammatory milieu is represented by human papillary thyroid carcinoma (PTC), a tumour characterized by the presence of chemokine-guided macrophage and dendritic cell infiltration (12-14). Rearrangements of the chromosome where is located the gene encoding the protein tyrosine kinase RET represent a frequent, early, causative, and sufficient genetic event in the pathogenesis of PTC. In an appropriate cellular context provided by primary human thyrocytes, the activation of RET induces a transcriptional programme connected to inflammation (12). In particular, the RET/PTC-activated transcriptome profile includes: colony-stimulating factors $\left(\mathrm{CSF}_{\mathrm{S}}\right)$, which promote leukocyte recruitment and survival; interleukin $1 \beta$ (IL-1 $1 \beta)$, one of the main inflammatory cytokines; cyclo-oxygenase 2 (COX2), frequently expressed in cancer and involved in the synthesis of prostaglandins; chemokines attracting monocytes and dendritic cells (CCL2, CCL20); angiogenic chemokines (CXCL8); co-ordinate induction and inhibition of matrix- 
degrading enzymes and inhibitors; up-regulation of L-selectin and expression of the chemokine receptor CXCR4 on the initiated cells (15). Key elements of the RET/PTC-activated inflammatory programme were found in biopsy specimens, and patients with lymph node metastasis showed higher levels of the inflammatory molecules in their primary tumours $(12,15,16)$. These results show that an early, causative, and sufficient genetic event (RET/PTC) involved in the pathogenesis of a human tumour directly promotes the build-up of an inflammatory microenvironment to its direct advantage (12).

More in general, different types of alterations concurring to tumour progression, such as activation of oncogenes, or inactivation of tumour suppressors, may trigger the inflammatory cascade. Members of the epidermal growth factor receptor (EGFR) family have tyrosine kinase activity and are frequently involved in human cancer. EGFR activation in glioma induces COX2 expression via p38mitogen-activated protein kinase (MAPK) activation of Sp1/Sp3 (17); COX2 is an independent prognostic factor in glioma. Ras family oncogenes, the most frequently mutated dominant oncogenes in human cancer, when activated, are able to induce expression and production of inflammatory mediators. Transfer of ras oncogene into a cervical carcinoma line (HeLa) induces the production of CXCL8 $(18,19)$, a chemokine which promotes angiogenesis and tumour progression. Moreover, miId chronic pancreatitis, possibly mirroring clinical epidemiology, acts in concert with $K$-ras mutation to induce pancreatic intra-epithelial neoplasia and invasive ductal carcinoma (20). Along the same lines Braf, frequently activated in malignant melanoma, induces cytokines which contribute to a pro-tumour milieu (21). Another oncogene, myc, encodes a transcription factor that is over-expressed in many human tumours: deregulation of this gene initiates and maintains key aspects of the tumour phenotype. In addition to promoting cell autonomous proliferation, myc instructs remodelling of the extracellular microenvironment with inflammatory cells and mediators playing key roles. The myc-activated genetic programme also includes several CC chemokines which recruit mast cells.
Mast cells, that have long been known to drive angiogenesis, here sustain new vessel formation and tumour growth (22).

Tumour suppressor proteins can also regulate the production of inflammatory mediators. Examples of such proteins are the von Hippel Lindau/hypoxia-inducible factor (VHL/HIF), transforming growth factor- $\beta$ (TGF- $\beta$ ) and phosphatase and tensin homologue (PTEN). The chemokine receptor CXCR4, frequently expressed on malignant cells and implicated in cell survival and metastasis, as well as TNF-a lies downstream of the VHL/HIF axis in human renal-cell carcinoma cells (23). In non-small cell lung cancer (NSCLC) mutation of PTEN results in up-regulation of HIF-1 activity and in HIF-1-dependent transcription of the CXCR4 gene, which promotes metastasis formation. In an animal model of breast carcinoma, inactivation of the gene encoding the type II TGF- $\beta$ receptor induces the production of CXCL5 and CXCL12, attracting myeloid-derived suppressor cells (MDSC) which facilitate metastasis $(24,25)$. Alpha catenin is more than a tumour suppressor sequestering beta-catenin: its ablation results in NFKB activation, induction of genes involved in inflammation, cell proliferation, wound-healing, and ultimately squamous cell carcinoma (26). The putative tumour suppressor semaphorin $3 \mathrm{~B}$ is also able to trigger an IL-8-mediated pro-metastatic programme, suggesting a multifaced role for this molecule (27). P53 has been connected to CXCR4 ligand expression. Indeed, within both human and mouse fibroblasts, p53 can suppress the production of CXCL12 and attenuate tumour development and metastasis (28).

Thus, oncogenes representative of different molecular classes and modes of action (tyrosine kinases, ras-raf, nuclear oncogenes) as well as tumour suppressor genes, share the capacity to orchestrate pro-inflammatory programmes (Figure 1). Although these responses may share common elements in several tissues (e.g. a link to angiogenesis, recruitment of cells of myelo-monocytic origin) some issues, such as the nature of inflammatory components, if they are essential or redundant, their role in different tissues and in different types of cancer, need to be elucidated. 


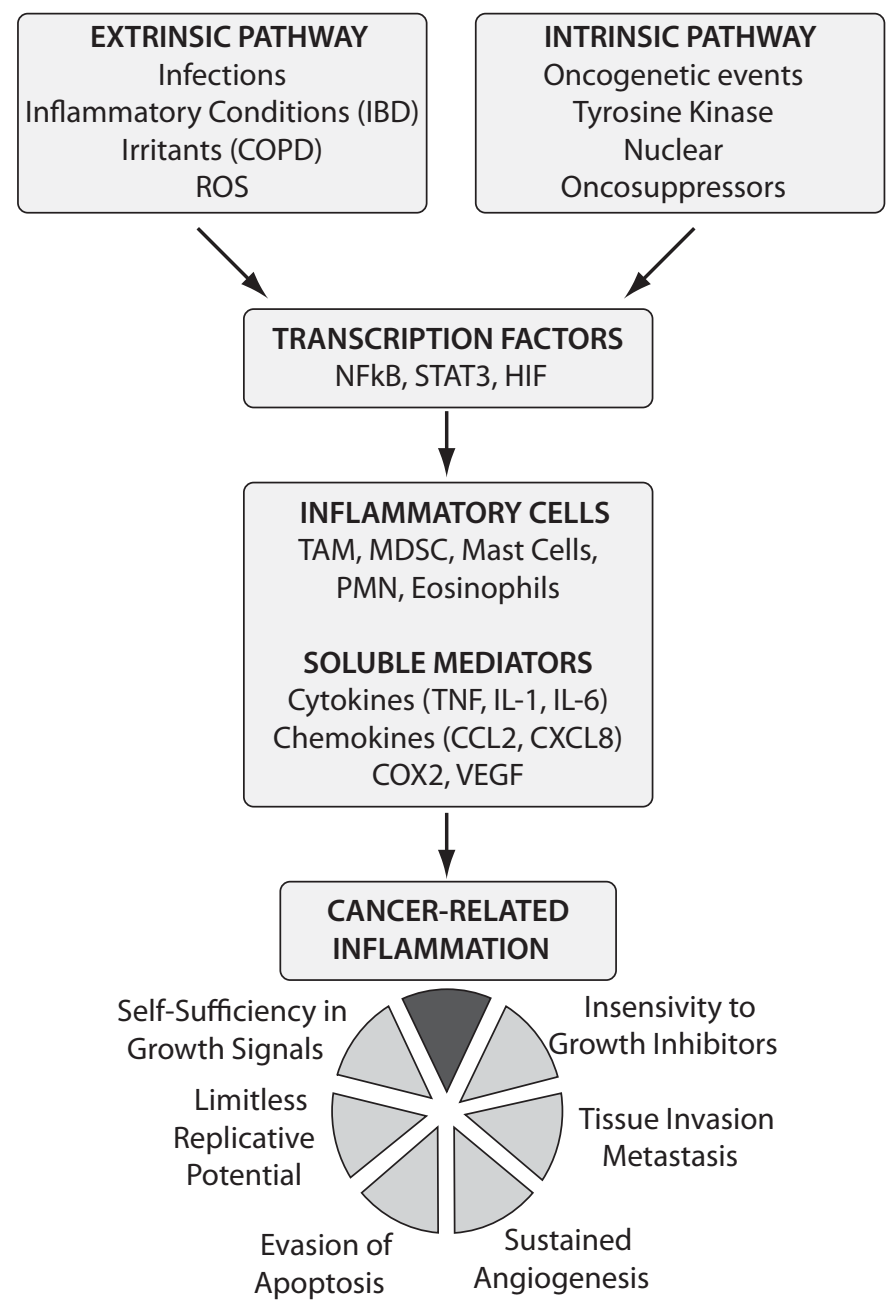

Figure 1. Molecular pathways linking inflammation and cancer. Two pathways can be identified as the major affluent to the inflammatory milieu: the intrinsic one, where genetic events (e.g. oncogenes) inducing neoplastic transformation trigger the inflammatory cascade, and the extrinsic pathway where chronic inflammation (e.g. infections, irritants) significantly increases the risk for different types of cancer. The two pathways converge, resulting in the activation of transcription factors (e.g. NFKB) that coordinate the production of inflammatory mediators and the activation of various leukocytes generating a cancer-related inflammatory microenvironment. CRI represents a recognized hallmark of cancer.

IBD - inflammatory bowel disease; COPD - chronic obstructive pulmonary disease; ROS - reactive oxygen species; NFKB - nuclear factor kappa B; STAT - signal transducers activator of transcription; HIF - hypoxia inducible factor; TAM - tumour associated macrophages; MDSC - myeloid-derived suppressor cells; PMN - polymorphic nuclear cells; COX2 - cyclo-oxygenase 2; VEGF - vascular endothelial growth factor.

\section{The extrinsic pathway}

In the extrinsic pathway, inflammation is mainly triggered by leukocytes producing inflammatory mediators. The implicated inflammatory conditions are quite diverse, including a wide array of chronic infections, exposure to noxious agents that trigger inflammation (e.g. gastric acid reflux, tobacco, asbestos) and auto-immune conditions $(22,29)$. The best established link between chronic inflammation and cancer is colorectal cancer that develops in patients with inflammatory bowel diseases (IBD, ulcerative colitis and Crohn disease). These patients have five- to seven-fold increased risk of developing colorectal cancer (43\% of patients with ulcerative colitis develop colorectal cancer after 25 to 35 years) (30). In a murine model of IBD, the development of colitis-associated colorectal cancer can be inhibited by blocking TNF- $a$ expression (31). Lung cancer is a leading cause of cancer deaths (32). Although tobacco exposure is evident in nearly $90 \%$ of all patients with lung cancer, other chronic airway inflammatory conditions (e.g. asbestosis, silicosis, exposure to airborne particulate matter, idiopathic pulmonary fibrosis, tuberculosis, etc) are all independent risk factors for lung cancer and may account for a proportion of the non-smoking related cases (33).

Reactive oxygen species (ROS) and nitrogen intermediates are obvious inflammation-generated candidate mediators for DNA damage, and evidence obtained in vitro and in vivo is consistent with this view (2). Recently, mitochondrial ROS production has been demonstrated to be required for mediating K-ras-induced lung cancer in mice (34). In addition, mitochondrial products released by damaged cell can activate inflammation and act as signalling molecules that trigger production of pro-inflammatory cytokines (35). Mitochondrial ROS have been recently shown to be induced by inflammasome activators, and these mitochondrial ROS are in turn required for the activation of the inflammasome (36). Overall, important new molecular pathways involving mitochondrial damage and ROS production are being elucidated that profoundly affect not only DNA damage and activation of oncogenes, but also different aspects of inflammation, suggesting an important role as upstream regulators of cancer-related signalling pathways that promote inflammation and tumorigenesis (37). 
Another example is represented by the aberrant expression of activation-induced cytidine deaminase (AID) that is induced in gastric epithelium by Helicobacter pylori (38). AID is a member of the cytidine-deaminase family that acts as a DNA- and RNA-editing enzyme. The H. pylori-mediated upregulation of AID resulted in the accumulation of nucleotide alterations in gastric cells, leading to the development of gastric cancer (38). In addition, the ectopic AID production, induced by TNF stimulation in human bile-duct cells, is associated with chronic biliary inflammation and the development of cholangiocarcinoma (39). Therefore, AID may link chronic inflammation to DNA damage in these tumours.

\section{Key orchestrators at the intersection pathway of cancer-related inflammation}

Among the molecular players involved in CRI, key endogenous promoters include transcription factors such as NFKB, signal transducer activator of transcription-3 (STAT3), and primary inflammatory cytokines such as IL-1 $\beta$, IL-6, IL-23, and TNF- $\alpha$ (8,40-42).

NFKB is a key orchestrator of innate immunity and inflammation and it has recently emerged as potential molecular bridge between tumour cells and inflammatory cells (40). In both cellular contexts, NFKB operates downstream of the sensing of microbes or tissue damage by the toll-like receptor (TLR)-MyD88 pathway, the inflammatory cytokines TNF- $\alpha$ and IL-1 $\beta$, and downstream of tissue damage that results in release of alarm signals. In addition, NFKB activation can be the result of cell-autonomous genetic alterations (amplification, mutations, or deletions) in cancer cells.

NFKB induces the expression of inflammatory cytokines, adhesion molecules, key enzymes in the prostaglandin synthase pathway (COX2), nitric oxide (NO) synthase, and angiogenic factors. In cancer and epithelial cells exposed to carcinogens, NFkB promotes cell survival and proliferation by the activation of genes encoding for proteins regulating cell cycle progression (e.g. cyclin D, c-myc) and apoptosis (e.g. clAPs, A1/BFL1, Bcl2, c-Flip). Hepatocarcinogenesis significantly depends on NFKB activation in both parenchymal (hepatocytes) and non parenchymal cells of the liver (43). Strong genetic evidence, including tissue-specific gene targeting of components of the lkk complex, such as IkappaB-kinase beta (IKK $\beta$ ), has demonstrated a crucial role of NFKB in tumour promotion in prototypic tissues of CRI (e.g. gastrointestinal tract and liver). IKKbeta regulates gastric carcinogenesis via IL-1a expression, which is associated with anti-apoptotic signaling and cell proliferation (44). Accumulating evidence suggests that intersections and compensatory pathways may exist between the NFKB and HIF-1 systems $(7,45,46)$ linking innate immunity to the hypoxic response.

The NFKB pathway is tightly controlled by inhibitors acting at different levels. Toll-interleukin receptor 8 (TIR8) is an example of a molecule that, by controlling inflammation, may protect against cancer. TIR8 also known as single immunoglobulin interleukin 1 receptor-related protein (SIGIRR), is a fringe member of the IL-1 receptor family with a single Ig domain, a long cytoplasmic tail and an altered TIR domain. It inhibits TLR and IL-1R signalli$\mathrm{ng}$ and is highly expressed in intestinal mucosa. TIR8 gene deficiency is associated with increased susceptibility to intestinal inflammation and carcinogenesis $(47,48)$ as well as to B cell lymphoproliferation and autoimmunity $(49,50)$. Another negative regulator of inflammation, namely A20 (also known as TNFAIP3), has been proposed to function as tumour suppressor in several human B-ceIl lymphoma (51).

Thus, balancing inhibitors and activators tunes the action of the NFKB pathway as an endogenous tumour promoter, acting in infiltrating leukocytes as well as in cells targeted by carcinogens. Evidence suggests that $\mathrm{p} 50$ homodimer-negative regulator is responsible for the sluggish NFKB activation in tumour-associated macrophages (TAM) and for their pro-tumour phenotype. Thus, NFkB appears to act as a rheostat tuned at different levels in florid inflammatory conditions predisposing to cancer (e.g. inflammatory bowel disease, IBD) and in TAMs sustaining the smouldering inflammatory milieu of established metastatic neoplasia $(52,53)$. NFKB has also been recently involved in driving the M2 (alternatively activated macrophages) polarization of TAMs (54). 
Along with NFKB, STAT3 is a point of convergence for numerous oncogenic signalling pathways (8). Constitutively activated STAT3 increases tumour cell proliferation, survival and invasion while suppressing anti-tumour immunity. The persistent activation of STAT3 also mediates tumour-promoting inflammation. STAT3 has this dual role in tumour inflammation and immunity by promoting pro-oncogenic inflammatory pathways, including NFKB and IL-6-gp130-JAK pathways and by opposing STAT1 and NFKB-mediated Th1 anti-tumour immune responses (55).

\section{Soluble mediators of cancer-related inflammation}

TNF-a plays a key role in the persistence of inflammation and established evidence demonstrates that tumour derived TNF-a sustains the growth and progression of syngenic, xenogenic and chemically induced tumours of skin, pancreas and bowels $(31,56,57)$. In addition to cancer cells, other TNF-a producers have been identified in tumour microenvironment. Macrophages (58) and CD4+ cells (59) secrete TNF- $a$ and trigger inflammation, as shown in a genetic model of liver cancer (43). TNF-a initiates a complex cross-talk between epithelial ovarian cancer cells and surrounding tissues, promoting the colonization of the peritoneum (59). Moreover, the constitutive production of TNF-a was associated with increased release of chemokines (CCL2, CXCL8, CXCL12), IL-6, VEGF and macrophage migration inhibitory factor (MIF-1). The mechanism of TNF- $a$ action includes direct effects on tumour spread, via CXCR4; tumour cell survival, via CXCR4/CXCL12; but also stimulation of new blood vessels in the peritoneal tumour colonies, due to induction of CXCL12 and VEGF expression (60). A major source of inflammatory cytokines in the tumour microenvironment are tumourassociated macrophages (TAM) $(61,62)$. TAMs promote wnt signalling through TNF in gastric cancer (63). These findings provide a rationale for the development of clinical protocols employing TNF antagonists in cancer therapy (64). Decoy receptor 3 (DcR3) is a member of the TNF receptor superfamily and has been involved in the control of MHC cla- ss II in TAMs (65). IL-1, IL-6, TNF- $a$, and the related receptor activator of NFKB ligand (RANKL) have long been known to augment the capacity to metastatize by affecting multiple steps in the dissemination and inflammation cascade $(2,66,67)$. TAMs assist tumour behaviour in many ways, including producing cytokines, growth factors, and matrixdegrading enzymes (68-70). Kim et al. recently showed that tumour cell supernatants contained an inducer of cytokine production in macrophages. Unexpectedly, the tumour-derived macrophage activation was identified as a component of the extracellular matrix: versican, which is frequently up-regulated in human tumours. Versican, released by tissue damage, was found to be recognized by toll-like receptor 2 and 6 (TLR2/TLR6). Thus, in the Lewis lung carcinoma model this study identifies a cascade of amplification of metastasis initiated by tumour-derived versican acting on myeloid cells via TLR2/TLR6, leading to inflammatory cytokine production (71).

The involvement of IL-1 in tumour progression is well established. IL-1 expression is elevated in human breast, colon, lung, head and neck cancers, melanomas, and patients with IL-1 producing tumours have generally bad prognosis (72). IL-1 promotes tumour growth and metastasis by inducing several pro-metastatic genes such as metalloproteinases, chemokines, growth factors and TGF- $\beta$ (73). IL-1 is also able to stimulate the expression of endothelial adhesion molecules such as ICAM-1 and VCAM-1 (74). Of particular importance are its effects on angiogenesis: IL-1 is a potent proangiogenic cytokine and VEGF release is also IL-1 dependent (75). In a pancreatic islet tumour model, a first wave of myc-driven angiogenesis is induced by the inflammatory cytokine IL-1 (76). IL-1a was also shown to play a pivotal role in the pathogenesis of liver cancer (77). On the other hand, IL-1a is possibly of importance in 3-methylcholantrene-induced fibrosarcoma, due to its efficiency in activating anti-tumour innate and specific immune responses, by acting as a focused adjuvant, through binding to IL-1R1 on immunesurveillance cells $(78,79)$. Moreover, small amounts of IL-1a, which is homeostatically expressed in cells, but not secreted, can be poured out from necrotizing cells and serve as a 
'danger signal' for mounting anti-tumour cell immunity (80). In 1993 the first study using IL-1R antagonist (IL-1Ra) treatment in mice transplanted with human melanoma cells demonstrated a strong reduction in the number of lung metastasis (81). Similar findings were reported in a model of hepatic metastasis: a single injection of IL-1Ra reduced tumor colonies by $50 \%$ and tumor volume by $70 \%$ (82). There is evidence of therapeutic efficacy in blocking the IL-1 pathway in humans with IL-1Ra and IL-1 inhibitors. In myeloma patients treated with dexamethasone and Anakinra (IL-1Ra) long progression-free intervals of over 3 years or 4 years were obtained in some patients (83) indicating a long stabilization of the disease. More potent IL-1 inhibitors are reaching clinical evaluation, in particular for autoimmune diseases, opening a possible future use in anti cancer therapies (84).

IL-6 is a key growth-promoting and anti-apoptotic inflammatory cytokine $(85,86)$ and is also one of the effector signals of activated NFKB in the promotion of neoplasia. A clear pro-tumoral role for IL-6 has been demonstrated in multiple myeloma (87). Another example of IL-6-dependent tumour is the Hepatocellular carcinoma (HCC), the most common type of liver cancer. Naugler et al. (88) explored the molecular mechanisms to explain the higher incidence of liver cancer in male patients. It turned out that in females estrogens block IL- 6 production in local immune cells (liver Kupffer celIs). In IL-6 deficient mice or mice lacking the adaptor protein MyD88 (linked to NFKB signalling) the sex difference in susceptibility to cancer was absent (89). The importance of the autocrine IL- 6 is confirmed also in other cancer types where it is demonstrated that IL- 6 is an important activator of oncogenic STAT3 in lung adenocarcinomas and Jagged-1/Notch signalling in breast tumour mammospheres (90-92). New light was shed on the role of IL-6 in colitis-associated cancer $(93,94)$. It was found that IL- 6 produced by myeloid cells is a critical tumour promoter during intestinal carcinogenesis. IL-6 protects normal and pre-malignant intestinal epithelial cells from apoptosis and promotes the proliferation of tumour-initiating cells. These actions are mediated by gp130 and STAT3. Thus, the NFKB/IL-6/STAT3 cascade plays a key role in in- testinal carcinogenesis. Interestingly, STAT3 also regulates the balance between IL-12 and IL-23 in the tumour microenvironment (95).

Another soluble component strictly associated with the recruitment of leukocytes in tumours is represented by chemokines $(2,9,96,97)$. Recent results with gene-targeted mice have provided unequivocal evidence for a role of CC chemokines in carcinogenesis. Mice deficient in D6, a decoy and scavenger receptor for inflammatory CC chemokines, show increased susceptibility to skin carcinogenesis and colitis-associated cancer (98). The contribution of chemokines to angiogenesis and tumour promotion has been the object of intensive investigation. A variety of chemokines, including CCL2, CXCL12, CXCL8, CXCL1, CXCL13, CCL5, CCL17, and CCL22, have been detected in neoplastic tissues as products of either tumour cells or stromal elements $(96,99)$. CXCL1 and related molecules (CXCL2, CXCL3, CXCL8, or IL-8) have an important role in melanoma progression by stimulating neoplastic growth, promoting inflammation, and inducing angiogenesis. Strong evidence demonstrates that levels of CCL2 are associated with TAM accumulation and that CCL2 may play an important role in the regulation of angiogenesis (1). Chemokines are also involved in the rapid turnover of myeloid-derived suppressor cells (100). Expression of chemokine receptors plays an important role in guiding metastasis. CXCR4 is the most frequently up-regulated chemokine receptor in cancer cells, and it is associated with advanced stages and metastasis (2). Recently, the chemokine receptor CX3CR1 has been reported to be up-regulated in human pancreatic cancer and to be involved in the perineural dissemination of this neoplasia along local nerve terminations (101).

\section{Cellular components of cancer-related inflammation}

TAM represent the major inflammatory component of the stroma of many tumours, able to affect different aspects of the neoplastic tissue $(102,103)$. In several studies of human cancer, TAM accumulation has been associated with angiogenesis and with the production of angiogenic factors such as 
VEGF and platelet derived endothelial cell growth factor (1,104-109). TAMs accumulate in hypoxic regions of tumours, and hypoxia triggers a pro-angiogenic programme in these cells (104). A number of molecules with possible impact on angiogenesis have been shown to be expressed by macrophages in low-oxygen conditions, such as VEGF, TNF-a, basic fibroblast growth factor (bFGF), and CXCL8. Therefore, macrophages recruited in situ represent an indirect pathway of amplification of angiogenesis, in concert with angiogenic molecules directly produced by tumour cells $(2,23)$. Under hypoxic conditions, tumour-secreted lactic acid promotes a IL-23/IL-17-mediated pro-inflammatory pathway in TAMs (110).

Myeloid cells in the tumour microenvironment are related to the angiogenic switch at different levels (111). VEGF and the related angiogenic factor placenta derived growth factor (PIDGF) have long been known to be potent monocyte attractants and to contribute to TAM recruitment (112). VEG$\mathrm{F} \mathrm{R}^{+}$hematopoietic bone-marrow cells home to tumour-specific premetastatic sites. There, they fo$\mathrm{rm}$ a recipient niche which favours secondary localization of cancer. Bv8, also known as prokinetic 2, modulates recruitment of angiogenic $\mathrm{Gr}^{+} \mathrm{Macl}^{+}$ cells from bone-marrow (113) and promotes angiogenesis. Moreover, $\mathrm{Gr}^{+} \mathrm{Mac1}^{+}$cells, presumably MDSC, have recently been shown to mediate resistance to anti-angiogenic therapy in various modeIs (113). However, also mast cells, neutrophils and even effectors of the adaptive immunity (e.g. antibody-producing $B$ cells activating macrophages) may sustain inflammatory reactions that promote cancer progression $(114,115)$. In addition to producing angiogenic factors, such as chemokines and VEGF itself, myeloid cells are also a source of matrix-degrading enzymes (MMP) which mobilize VEGF from extracellular matrix stores. Recent results suggest that TAMs can promote tumour angiogenesis also via semaphorin 4D (116). Thus TAMs and related cells (MDSC, DC, polymorphonuclear cells (PMN)) represent an important indirect and alternative pathway of angiogenesis in the tumour microenvironment (117).

\section{Concluding remarks}

The link between inflammation and cancer is now well established, even in those cases where underlying chronic infections are absent. Two molecular pathways have been recognized and consist of an intrinsic pathway, driven by genetic alterations that cause neoplasia and activate the inflammation cascade, and an extrinsic pathway where inflammatory conditions facilitate cancer development. At the crossroads, the key orchestrators are represented by transcription factors (e.g. NFKB) that coordinate cytokine (e.g. TNF), chemokine and enzyme production. These factors recruit and activate leukocytes, mainly of the myelomonocytic lineage (112), producing and amplifying the inflammatory responses. Smouldering inflammation contributes to proliferation and survival of malignant cells, angiogenesis, metastasis, subversion of adaptive immunity and reduced response to chemotherapeutic agents.

CRI represents a target for pharmacological strategies that can modulate the host microenvironment. Primary pro-inflammatory cytokines, chemokines and their receptors represent prime targets of future biological therapies (57), and their clinical use is being experimented in cancer patients (118120). Recently, new strategies are aimed at targeting TAM recruitment and polarization (53). For many years all efforts to treat cancer have concentrated only on the destruction/inhibition of cancer cells, CRI may represent a complementary perspective that can help the development of effective anti-tumour responses.

\section{Acknowledgements}

The authors are supported by the Italian Association for Cancer Research, Italian Ministry of Health, MIUR (Ministero dell'Istruzione Università e Ricerca).

\section{Potential conflict of interest}

None declared. 


\section{References}

1. Balkwill F, Mantovani A. Inflammation and cancer: back to Virchow? Lancet 2001;357:539-5.

2. Mantovani A, Allavena P, Sica A, Balkwill F. Cancer-related inflammation. Nature 2008;454:436-4.

3. Mantovani A, Garlanda C, Allavena P. Molecular pathways and targets in cancer-related inflammation. Ann Med 2010;42:161-70.

4. Rothwell PM, Fowkes FG, Belch JF, Ogawa H, Warlow $C P$, Meade TW. Effect of daily aspirin on long-term risk of death due to cancer: analysis of individual patient data from randomised trials. Lancet 2011;377:31-41.

5. Menter DG, Schilsky RL, DuBois RN. Cyclooxygenase-2 and cancer treatment: understanding the risk should be worth the reward. Clin Cancer Res 2010;16:1384-90.

6. Vannucci L, Stepankova R, Grobarova V, Kozakova H, Rossmann $P$, Klimesova $K$, et al. Colorectal carcinoma: Importance of colonic environment for anti-cancer response and systemic immunity. J Immunotoxicol 2009;6:217-26.

7. Rius J, Guma M, Schachtrup C, Akassoglou K, Zinkernagel $A S$, Nizet $V$, et al. NF-kappaB links innate immunity to the hypoxic response through transcriptional regulation of $\mathrm{HI}-$ F-1alpha. Nature 2008;453:807-11.

8. Yu $H$, Pardoll $D$, Jove R. STATs in cancer inflammation and immunity: a leading role for STAT3. Nat Rev Cancer 2009;9:798-09.

9. Allavena P, Germano G, Marchesi F, Mantovani A. Chemokines in cancer related inflammation. Exp Cell Res 2011;317:664-73.

10. Mantovani A. Cancer: Inflaming metastasis. Nature 2009;457:36-7.

11. Hanahan $D$, Weinberg RA. Hallmarks of cancer: the next generation. Cell 2011;144:646-74.

12. Borrello MG, Alberti L, Fischer A, Degl'innocenti D, Ferrario $C$, Gariboldi $M$, et al. Induction of a proinflammatory program in normal human thyrocytes by the RET/PTC1 oncogene. Proc Natl Acad Sci U S A 2005;102:14825-30.

13. Russell JP, Engiles JB, Rothstein JL. Proinflammatory mediators and genetic background in oncogene mediated tumor progression. J Immunol 2004;172:4059-67.

14. Russell JP, Shinohara S, Melillo RM, Castellone MD, Santoro $M$, Rothstein JL. Tyrosine kinase oncoprotein, RET/PTC3, induces the secretion of myeloid growth and chemotactic factors. Oncogene 2003;22:4569-77.

15. Cerutti JM, OlerG, Michaluart P, Delcelo R, Beaty RM, Shoemaker J, Riggins GJ. Molecular profiling of matched samples identifies biomarkers of papillary thyroid carcinoma lymph node metastasis. Cancer Res 2007;67:7885-92.

16. De Falco V, Guarino V, Avilla E, Castellone MD, Salerno $P$, Salvatore $G$, et al. Biological role and potential therapeutic targeting of the chemokine receptor CXCR4 in undifferentiated thyroid cancer. Cancer Res 2007;67:11821-9.

17. $X u K$, Shu HK. EGFR activation results in enhanced cyclooxygenase-2 expression through p38 mitogen-activated protein kinase-dependent activation of the Sp1/ Sp3 transcription factors in human gliomas. Cancer Res 2007;67:6121-9.
18. Masih-Khan E, Trudel S, Heise C, Li Z, Paterson J, Nadeem $V$, et al. MIP-1alpha (CCL3) is a downstream target of FGFR3 and RAS-MAPK signaling in multiple myeloma. Blood 2006;108:3465-71

19. Wang D, Wang H, Brown J, Daikoku T, Ning W, Shi Q, et al. CXCL1 induced by prostaglandin E2 promotes angiogenesis in colorectal cancer. J Exp Med 2006;203:941-51.

20. Guerra C, Schuhmacher AJ, Canamero M, Grippo PJ, Verdaguer L, Perez-Gallego L, et al. Chronic pancreatitis is essential for induction of pancreatic ductal adenocarcinoma by KRas oncogenes in adult mice. Cancer Cell 2007;11:291-02.

21. Sumimoto $H$, Imabayashi $F$, Iwata $T$, Kawakami $Y$. The BRAF-MAPK signaling pathway is essential for cancer-immune evasion in human melanoma cells. J Exp Med 2006;203:1651-6.

22. Soucek L, Lawlor ER, Soto D, Shchors K, Swigart LB, Evan Gl. Mast cells are required for angiogenesis and macroscopic expansion of Myc-induced pancreatic islet tumors. Nat Med 2007;13:1211-8.

23. Balkwill F, Charles KA, Mantovani A. Smoldering and polarized inflammation in the initiation and promotion of malignant disease. Cancer Cell 2005;7:211-7.

24. Bierie B, Moses HL. TGF-beta and cancer. Cytokine Growth Factor Rev 2006;17:29-40.

25. Yang L, Huang J, Ren X, Gorska AE, Chytil A, Aakre M, et al. Abrogation of TGF beta signaling in mammary carcinomas recruits $\mathrm{Gr}-1+\mathrm{CD} 11 b+$ myeloid cells that promote metastasis. Cancer Cell 2008;13:23-35.

26. Kobielak A, Fuchs E. Links between alpha-catenin, NF-kappaB, and squamous cell carcinoma in skin. Proc Natl Acad Sci U S A 2006;103:2322-7.

27. Rolny C, Capparuccia L, Casazza A, Mazzone M, Vallario $A$, Cignetti $A$, et al. The tumor suppressor semaphorin $3 B$ triggers a prometastatic program mediated by interleukin 8 and the tumor microenvironment. J Exp Med 2008;205:1155-71.

28. Moskovits N, Kalinkovich A, Bar J, Lapidot T, Oren M. p53 Attenuates cancer cell migration and invasion through repression of SDF-1/CXCL12 expression in stromal fibroblasts. Cancer Res 2006;66:10671-6.

29. Kamp DW, Shacter E, Weitzman SA. Chronic inflammation and cancer: the role of the mitochondria. Oncology (Williston Park) 2011;25:400-13.

30. Ferrone C, Dranoff G. Dual roles for immunity in gastrointestinal cancers. J Clin Oncol 2010;28:4045-51.

31. Popivanova BK, Kitamura $K, W u Y$, Kondo T, Kagaya T, Kaneko $S$, et al. Blocking TNF-alpha in mice reduces colorectal carcinogenesis associated with chronic colitis. J Clin Invest 2008;118:560-70.

32. Goldkorn T, Filosto S. Lung injury and cancer: Mechanistic insights into ceramide and EGFR signaling under cigarette smoke. Am J Respir Cell Mol Biol 2010;43:259-68.

33. Yao H, Rahman I. Current concepts on the role of inflammation in COPD and lung cancer. Curr Opin Pharmacol 2009;9:375-83.

34. Weinberg F, Hamanaka R, Wheaton WW, Weinberg S, Joseph J, Lopez $M$, et al. Mitochondrial metabolism and ROS generation are essential for Kras-mediated tumorigenicity. Proc Natl Acad Sci U S A 2010;107:8788-93. 
35. Naik E, Dixit VM. Mitochondrial reactive oxygen species drive proinflammatory cytokine production. J Exp Med 2011;208:417-20.

36. Zhou R, Yazdi AS, Menu P, Tschopp J. A role for mitochondria in NLRP3 inflammasome activation. Nature 2011;469:221-5.

37. Ralph SJ, Rodriguez-Enriquez S, Neuzil J, Saavedra E, Moreno-Sanchez $R$. The causes of cancer revisited: "mitochondrial malignancy" and ROS-induced oncogenic transformation - why mitochondria are targets for cancer therapy. Mol Aspects Med 2010;31:145-70.

38. Matsumoto Y, Marusawa H, Kinoshita K, Endo Y, Kou T, Morisawa $T$, et al. Helicobacter pylori infection triggers aberra$n$ t expression of activation-induced cytidine deaminase in gastric epithelium. Nat Med 2007;13:470-6.

39. Komori J, Marusawa H, Machimoto T, Endo Y, Kinoshita K, Kou T, et al. Activation-induced cytidine deaminase links bile duct inflammation to human cholangiocarcinoma. Hepatology 2008;47:888-96.

40. Karin M. Nuclear factor-kappaB in cancer development and progression. Nature 2006;441:431-6.

41. Voronov E, Shouval DS, Krelin Y, Cagnano E, Benharroch D, Iwakura $Y$, et al. IL-1 is required for tumor invasiveness and angiogenesis. Proc Natl Acad Sci USA 2003;100:2645-50.

42. Langowski JL, Zhang $X, W u$ L, Mattson JD, Chen T, Smith $K$, et al. IL-23 promotes tumour incidence and growth. Nature 2006;442:461-5.

43. Pikarsky E, Porat RM, Stein I, Abramovitch R, Amit S, Kasem $S$, et al. NF-kappaB functions as a tumour promoter in inflammation-associated cancer. Nature 2004;431:461-6.

44. Sakamoto K, Hikiba Y, Nakagawa H, Hayakawa Y, Yanai A, Akanuma $M$, et al. Inhibitor of kappaB kinase beta regulates gastric carcinogenesis via interleukin-1alpha expression. Gastroenterology 2010;139:226-38.

45. Carbia-Nagashima A, Gerez J, Perez-Castro C, Paez-Pereda $M$, Silberstein S, Stalla GK, et al. RSUME, a small RWD-containing protein, enhances SUMO conjugation and stabilizes HIF-1 alpha during hypoxia. Cell 2007;131:309-23.

46. Jung YJ, Isaacs JS, Lee S, Trepel J, Neckers L. IL-1 beta-mediated up-regulation of HIF-1alpha via an NFkappaB/COX-2 pathway identifies HIF-1 as a critical link between inflammation and oncogenesis. FASEB J 2003;17:2115-7.

47. Garlanda C, Riva F, Veliz T, Polentarutti N, Pasqualini F, Radaelli $E$, et al. Increased susceptibility to colitis-associated cancer of mice lacking TIR8, an inhibitory member of the interleukin-1 receptor family. Cancer Res 2007; 67:6017-21.

48. Xiao H, Gulen F, Qin J, Yao J, Bulek K, Kish D, et al. The ToII-interleukin-1 receptor member SIGIRR regulates colonic epithelial homeostasis, inflammation, and tumorigenesis. Immunity 2007;26:461-75.

49. Lech M, Kulkarni OP, Pfeiffer S, Savarese E, Krug A, Garlanda $C$, et al. Tir8/Sigirr prevents murine lupus by suppressing the immunostimulatory effects of lupus autoantigens. J Exp Med 2008;205:1879-88.

50. Bertilaccio MT, Simonetti G, Dagklis A, Rocchi M, Veliz Rodriguez $T$, Apollonio $B$, et al. Lack of TIR8/SIGIRR triggers progression of chronic lymphocytic leukemia in mouse models. Blood 2011; 118:660-9.

51. Verstrepen L, Verhelst K, van Loo G, Carpentier I, Ley SC, Beyaert R. Expression, biological activities and mechanisms of action of A20 (TNFAIP3). Biochem Pharmacol 2010;80:2009-20.
52. Biswas SK, Gangi L, Paul S, Schioppa T, Saccani A, Sironi $M$, et al. A distinct and unique transcriptional program expressed by tumor-associated macrophages (defective NF-kappaB and enhanced IRF-3/STAT1 activation). Blood 2006; 107:2112-22.

53. Sica A. Role of tumour-associated macrophages in cancerrelated inflammation. Exp Oncol 2010;32:153-8.

54. Hagemann $T$, Lawrence $T$, McNeish I, Charles KA, Kulbe $H$, Thompson RG, et al. "Re-educating" tumor-associated macrophages by targeting NF-kappaB. J Exp Med 2008;205:1261-8.

55. Kortylewski M, Kujawski M, Wang T, Wei S, Zhang S, PilonThomas S, et al. Inhibiting Stat3 signaling in the hematopoietic system elicits multicomponent antitumor immunity. Nat Med 2005;11:1314-21.

56. Moore RJ, Owens DM, Stamp G, Arnott C, Burke F, East N, et al. Mice deficient in tumor necrosis factor-alpha are resistant to skin carcinogenesis. Nat Med 1999;5:828-31.

57. Balkwill F. Tumour necrosis factor and cancer. Nat Rev Cancer 2009;9:361-71.

58. Hagemann T, Wilson J, Kulbe H, Li NF, Leinster DA, Charles K, et al. Macrophages induce invasiveness of epithelial cancer cells via NF-kappa B and JNK. J Immunol 2005;175:1197-05.

59. Charles KA, Kulbe H, Soper R, Escorcio-Correia M, Lawrence $T$, Schultheis $A$, et al. The tumor-promoting actions of TNFalpha involve TNFR1 and IL-17 in ovarian cancer in mice and humans. J Clin Invest 2009;119:3011-23.

60. Kulbe H, Thompson R, Wilson JL, Robinson S, Hagemann $T$, Fatah $R$, et al. The inflammatory cytokine tumor necrosis factor-alpha generates an autocrine tumor-promoting network in epithelial ovarian cancer cells. Cancer Res 2007;67:585-92.

61. Mantovani A, Sozzani S, Locati M, Allavena P, Sica A. Macrophage polarization: tumor-associated macrophages as a paradigm for polarized M2 mononuclear phagocytes. Trends Immunol 2002;23:549-55.

62. Sica A, Schioppa T, Mantovani A, Allavena A. Tumour-associated macrophages are a distinct M2 polarised population promoting tumour progression: potential targets of anti-cancer therapy. Eur J Cancer 2006;42:717-27.

63. Oguma K, Oshima H, Aoki M, Uchio R, Naka K, Nakamura $S$, et al. Activated macrophages promote Wnt signalling through tumour necrosis factor-alpha in gastric tumour cells. EMBO J 2008;27:1671-81.

64. Harrison ML, Obermueller E, Maisey NR, Hoare S, Edmonds $K$, Li NF, et al. Tumor necrosis factor alpha as a new target for renal cell carcinoma: two sequential phase II triaIs of infliximab at standard and high dose. J Clin Oncol 2007;25:4542-9.

65. Chang YC, Chen TC, Lee CT, Yang CY, Wang HW, Wang CC, Hsieh SL. Epigenetic control of MHC class II expression in tumor-associated macrophages by decoy receptor 3. Blood 2008; 111:5054-63.

66. Giavazzi R, Garofalo A, Bani MR, Abbate M, Ghezzi P, Boraschi $D$, et al. Interleukin 1-induced augmentation of experimental metastases from a human melanoma in nude mice. Cancer Res 1990;50:4771-5.

67. Luo JL, Tan W, Ricono JM, Korchynskyi O, Zhang M, Gonias $S L$, et al. Nuclear cytokine-activated IKKalpha controIs prostate cancer metastasis by repressing Maspin. Nature 2007;446:690-4. 
68. Wyckoff JB, Wang Y, Lin EY, Li JF, Goswami S, Stanley ER, et al. Direct visualization of macrophage-assisted tumor cell intravasation in mammary tumors. Cancer Res 2007;67:2649-56.

69. Mantovani A, Schioppa T, Porta C, Allavena P, Sica A. Role of tumor-associated macrophages in tumor progression and invasion. Cancer Metastasis Rev 2006;25:315-22.

70. Condeelis J, Pollard JW. Macrophages: obligate partners for tumor cell migration, invasion, and metastasis. Cell 2006;124:263-6.

71. Kim S, Takahashi H, Lin WW, Descargues P, Grivennikov S, Luo $\mathrm{J}$, et al. Carcinoma-produced factors activate myeloid cells through TLR2 to stimulate metastasis. Nature 2009:457:102-6.

72. Naldini A, Filippi I, Miglietta D, Moschetta M, Giavazzi $R$, Carraro F. Interleukin-1 beta regulates the migratory potential of MDAMB231 breast cancer cells through the hypoxiainducible factor-1 alpha. Eur J Cancer 2010;46:3400-8.

73. Dinarello CA. The paradox of pro-inflammatory cytokines in cancer. Cancer Metastasis Rev 2006;25:307-13.

74. Arguello F, Baggs RB, Graves BT, Harwell SE, Cohen HJ, Frantz CN. Effect of IL-1 on experimental bone/bone-marrow metastases. Int J Cancer 1992;52:802-7.

75. Carmi Y, Voronov E, Dotan S, Lahat N, Rahat MA, Fogel M, et al. The role of macrophage-derived IL-1 in induction and maintenance of angiogenesis. J Immunol 2009;183:4705-14.

76. Shchors K, Shchors E, Rostker F, Lawlor ER, Brown-Swigart L, Evan Gl. The Myc-dependent angiogenic switch in tumors is mediated by interleukin 1beta. Genes Dev 2006;20:252738.

77. Sakurai T, He G, Matsuzawa A, Yu GY, Maeda S, Hardiman $G$, Karin M. Hepatocyte necrosis induced by oxidative stress and IL-1 alpha release mediate carcinogen-induced compensatory proliferation and liver tumorigenesis. Cancer $\mathrm{Ce}$ II 2008;14:156-65.

78. Marhaba R, Nazarenko I, Knofler D, Reich E, Voronov E, Vitacolonna $M$, et al. Opposing effects of fibrosarcoma cellderived IL-1 alpha and IL-1 beta on immune response induction. Int J Cancer 2008;123:134-45.

79. Elkabets $M$, Krelin Y, Dotan S, Cerwenka A, Porgador A, Lichtenstein RG, et al. Host-derived interleukin-1alpha is important in determining the immunogenicity of 3-methylcholantrene tumor cells. J Immunol 2009;182:4874-81.

80. Chen CJ, Kono H, Golenbock D, Reed G, Akira S, Rock KL. Identification of a key pathway required for the sterile inflammatory response triggered by dying cells. Nat Med 2007;13:851-6.

81. Chirivi RG, Garofalo A, Padura IM, Mantovani A, Giavazzi $R$. Interleukin 1 receptor antagonist inhibits the augmentation of metastasis induced by interleukin 1 or lipopolysaccharide in a human melanoma/nude mouse system. Cancer Res 1993;53:5051-4.

82. Vidal-Vanaclocha F, Amezaga C, Asumendi A, Kaplanski G, Dinarello CA. Interleukin-1 receptor blockade reduces the number and size of murine B16 melanoma hepatic metastases. Cancer Res 1994;54:2667-72.

83. Lust JA, Lacy MQ, Zeldenrust SR, Dispenzieri A, Gertz MA, Witzig TE, et al. Induction of a chronic disease state in patients with smoldering or indolent multiple myeloma by targeting interleukin 1\{beta\}-induced interleukin 6 production and the myeloma proliferative component. Mayo Clin Proc 2009;84:114-22.

84. Dinarello CA. Why not treat human cancer with interleukin-1 blockade? Cancer Metastasis Rev 2010;29:317-29.

85. Lin WW, Karin M. A cytokine-mediated link between innate immunity, inflammation, and cancer. J Clin Invest 2007;117:1175-83.

86. Naugler WE, Karin M. The wolf in sheep's clothing: the role of interleukin- 6 in immunity, inflammation and cancer. Trends Mol Med 2008;14:109-19.

87. Pal R, Janz M, Galson DL, Gries M, Li S, Johrens K, et al. C/ EBPbeta regulates transcription factors critical for proliferation and survival of multiple myeloma cells. Blood 2009;114:3890-8.

88. Naugler WE, Sakurai T, Kim S, Maeda S, Kim K, Elsharkawy $A M$, Karin M. Gender disparity in liver cancer due to sex differences in MyD88-dependent IL-6 production. Science 2007;317:121-4.

89. Rakoff-Nahoum S, Medzhitov R. Regulation of spontaneous intestinal tumorigenesis through the adaptor protein MyD88. Science 2007;317:124-7.

90. Gao SP, Mark KG, Leslie K, Pao W, Motoi N, Gerald WL, et al. Mutations in the EGFR kinase domain mediate STAT3 activation via IL-6 production in human lung adenocarcinomas. J Clin Invest 2007;117:3846-56.

91. Grivennikov S, Karin M. Autocrine IL-6 signaling: a key event in tumorigenesis? Cancer Cell 2008;13:7-9.

92. Sansone P, Storci G, Tavolari S, Guarnieri T, Giovannini C, Taffurelli $M$, et al. IL-6 triggers malignant features in mammospheres from human ductal breast carcinoma and normal mammary gland. J Clin Invest 2007;117:3988-4002.

93. Bollrath J, Phesse TJ, von Burstin VA, Putoczki T, Bennecke $M$, Bateman $T$, et al. gp130-mediated Stat3 activation in enterocytes regulates cell survival and cell-cycle progression during colitis-associated tumorigenesis. Cancer Cell 2009;15:91-102.

94. Grivennikov S, Karin E, Terzic J, Mucida D, Yu GY, Vallabhapurapu S, et al. IL-6 and Stat3 are required for survival of intestinal epithelial cells and development of colitis-associated cancer. Cancer Cell 2009;15:103-13.

95. Kortylewski $M$, Xin H, Kujawski M, Lee H, Liu Y, Harris T, et al. Regulation of the IL-23 and IL-12 balance by Stat3 signaling in the tumor microenvironment. Cancer Cell 2009;15:114-23.

96. Balkwill F. Cancer and the chemokine network. Nat Rev Cancer 2004;4:540-50.

97. Lazennec G, Richmond A. Chemokines and chemokine receptors: new insights into cancer-related inflammation. Trends Mol Med 2010;16:133-44.

98. Nibbs RJ, Gilchrist DS, King V, Ferra A, Forrow S, Hunter KD, Graham GJ. The atypical chemokine receptor D6 suppresses the development of chemically induced skin tumors. $J$ Clin Invest 2007; 117:1884-92.

99. Mantovani A, Savino B, Locati M, Zammataro L, Allavena $P$, Bonecchi $R$. The chemokine system in cancer biology and therapy. Cytokine Growth Factor Rev 2010;21:27-39.

100. Sawanobori Y, Ueha S, Kurachi M, Shimaoka T, Talmadge JE, Abe J, et al. Chemokine-mediated rapid turnover of myeloid-derived suppressor cells in tumor-bearing mice. Blood 2008; 111:5457-66. 
101. Marchesi F, Piemonti L, Fedele G, Destro A, Roncalli M, Albarello $L$, et al. The chemokine receptor $C X 3 C R 1$ is involved in the neural tropism and malignant behavior of pancreatic ductal adenocarcinoma. Cancer Res 2008;68:9060-9.

102. Mantovani A, Sica A. Macrophages, innate immunity and cancer: balance, tolerance, and diversity. Curr Opin Immunol 2010;22:231-7.

103. Solinas G, Marchesi F, Garlanda C, Mantovani A, Allavena P. Inflammation-mediated promotion of invasion and metastasis. Cancer Metastasis Rev 2010;29:243-8.

104. Du R, Lu KV, Petritsch C, Liu P, Ganss R, Passegue E, et al. HIF1alpha induces the recruitment of bone marrow-derived vascular modulatory cells to regulate tumor angiogenesis and invasion. Cancer Cell 2008;13:206-20.

105. Dineen SP, Lynn KD, Holloway SE, Miller AF, Sullivan JP, Shames DS, et al. Vascular endothelial growth factor receptor 2 mediates macrophage infiltration into orthotopic pancreatic tumors in mice. Cancer Res 2008;68:4340-6.

106. Kusmartsev S, Eruslanov E, Kubler H, Tseng T, Sakai Y, Su $Z$, et al. Oxidative stress regulates expression of VEGFR1 in myeloid cells: link to tumor-induced immune suppression in renal cell carcinoma. J Immunol 2008;181:346-53.

107. Duluc D, Delneste Y, Tan F, Moles MP, Grimaud L, Lenoir J, et al. Tumor-associated leukemia inhibitory factor and IL-6 skew monocyte differentiation into tumor-associated macrophage-like cells. Blood 2007;110:4319-30.

108. Robinson-Smith TM, Isaacsohn I, Mercer CA, Zhou M, Van Rooijen N, Husseinzadeh N, et al. Macrophages mediate inflammation-enhanced metastasis of ovarian tumors in mice. Cancer Res 2007;67:5708-16.

109. Stearman RS, Dwyer-Nield L, Grady MC, Malkinson AM, Geraci $M W$. A macrophage gene expression signature defines a field effect in the lung tumor microenvironment. Cancer Res 2008;68:34-43.

110. Shime H, Yabu M, Akazawa T, Kodama K, Matsumoto M, Seya T, Inoue N. Tumor-secreted lactic acid promotes IL-23/IL17 proinflammatory pathway. J Immunol 2008;180:7175-83.
111. Murdoch $C$, Muthana M, Coffelt SB, Lewis CE. The role of myeloid cells in the promotion of tumour angiogenesis. Nat Rev Cancer 2008;8:618-31.

112. Fischer C, Jonckx B, Mazzone M, Zacchigna S, Loges S, Pattarini $L$, et al. Anti-PIGF inhibits growth of VEGF(R)-inhibitor-resistant tumors without affecting healthy vessels. CeII 2007;131:463-75.

113. Shojaei F, Wu X, Malik AK, Zhong C, Baldwin ME, Scha$n z S$, et al. Tumor refractoriness to anti-VEGF treatment is mediated by CD11b+Gr1+ myeloid cells. Nat Biotechnol 2007;25:911-20.

114. de Visser KE, Eichten A, Coussens LM. Paradoxical roles of the immune system during cancer development. Nat Rev Cancer 2006;6:24-37.

115. Galli SJ, Grimbaldeston M, Tsai M. Immunomodulatory mast cells: negative, as well as positive, regulators of immunity. Nat Rev Immunol 2008;8:478-86.

116. Sierra JR, Corso S, Caione L, Cepero V, Conrotto P, Cignetti $A$, et al. Tumor angiogenesis and progression are enhanced by Sema4D produced by tumor-associated macrophages. $J$ Exp Med 2008;205:1673-85.

117. Noonan DM, De Lerma Barbaro A, Vannini N, Mortara $L$, Albini A. Inflammation, inflammatory cells and angiogenesis: decisions and indecisions. Cancer Metastasis Rev 2008;27:31-40.

118. Loberg RD, Ying C, Craig M, Yan L, Snyder LA, Pienta KJ. CCL2 as an important mediator of prostate cancer growth in vivo through the regulation of macrophage infiltration. Neoplasia 2007;9:556-62.

119. Porvasnik S, Sakamoto N, Kusmartsev S, Eruslanov E, Kim WJ, Cao W, et al. Effects of CXCR4 antagonist CTCE-9908 on prostate tumor growth. Prostate 2009;69:1460-9.

120. Richert MM, Vaidya KS, Mills CN, Wong D, Korz W, Hurst DR, Welch DR. Inhibition of CXCR4 by CTCE-9908 inhibits breast cancer metastasis to lung and bone. Oncol Rep 2009;21:761-7.

\section{Molekularni putovi u upali povezanoj s karcinomom}

\section{Sažetak}

Sve više dokaza ukazuje da je kronična upala povezana s povišenim rizikom od karcinoma. Upalna sastavnica prisutna je i u mikrookruženju tumora epidemiološki nepovezanog s upalom. Opsežna istraživanja provedena zadnjih deset godina otkrila su mnoge mehaničke putove koji su u podlozi upale povezane s karcinomom. Pronađeni su putovi koji povezuju upalu i karcinom: intrinzični (vođeni genetskim događajima koji uzrokuju neoplaziju) i ekstrinzični (vođeni upalnim uvjetima koji predodređuju karcinom). Tinjajuća upala sastavnica je tumorskog mikrookruženja te je prepoznata kao znak karcinoma. Glavni upravljači na presijecanju intrinzičnih i ekstrinzičnih putova obuhvaćaju transkripcijske čimbenike, primjerice nuklearni čimbenik kappa-B (NFkB), koji modulira upalni odgovor preko topljivih medijatora (citokina, kemokina) i staničnih sastavnica (npr. makrofaga povezanih s tumorom) pospješujući stvaranje tumora. NFkB pomaže kod proliferacije i preživljavanja malignih stanica, pospješuje angiogenezu i metastazu, narušava adaptivni imunitet te mijenja odgovore na hormone i kemoterapijske agente. Sve je više dokaza koji ukazuju da trajna upala pospješuje genetsku nestabilnost. Upala povezana s karcinomom stoga predstavlja cilj inovativne dijagnostike i terapijskih strategija.

Ključne riječi: upala povezana s karcinomom; citokini; kemokini; makrofagi 